\title{
CONVERTING TO ISLAM
}

\author{
Segu Atio \\ Pontianak State College of Islamic Studies
}

\begin{abstract}
Despite the fact that early Chinese expeditions to this country were led by a Muslim Chinese named Zheng He (Cheng Ho), the overwhelming majority of Chinese Indonesians currently embrace religions other than Islam. This article aims to give a first-hand account of a Chinese woman who converted to Islam and the stereotypical opinion commonly held among Chinese Indonesians, particularly those living in Pontianak, about it. This article also looks at why a conversion to Islam is always seen with a puzzled frown.
\end{abstract}

Keyword: Convert, Islam, Chinesse

\section{INTRODUCTION}

To understand the phenomenon of Islam among Indonesians of Chinese descent or better known as Tionghoa people in the local context, one needs to look at the history of the relations between Chinese Indonesians and their fellow indigenous Indonesians. But first, let us look at the use of the term Tionghoa itself. Tionghoa, as Chinese Indonesians are commonly referred to in this country, is a term that distinguishes between the Chinese diaspora in Indonesia and those in other countries such as Malaysia, Singapore, etc. Interestingly, the term suku Tionghoa which literally means ethnic Chinese is often used to identify Chinese Indonesians as one of the ethnic groups in addition to other groups found in West Kalimantan. Although linguistically, the word Tionghoa (Mandarin 中华 Chung Hua) means "of or relating to China or the Chinese people".

To avoid stereotypes and subjectivity, this paper is merely a reflection of the author's opinion and does not necessarily reflect the general opinion of the Chinese society of West Kalimantan. The author's views are the result of the observation, personal experience and the discussions held with the respondents.

Converting to Islam among Chinese Indonesians, hereafter referred to as the Chinese, is often opposed by the family. In some families, this conversion may result in a person being disowned or becoming estranged from the family. Converting to Islam is regarded as a disgrace that must be covered up. If a girl is married to a Muslim man, it is very common for her parents to conceal the 
fact by saying that their daughter is working in another city or moved with her husband to an unspecified place. When asked about her to other members of the family, they refuse to talk about her or simply change the subject of the conversation. When asked again, the most common verbal response would be "it's slap in the face." Thus, it is not uncommon for parents to attempt to persuade their children to revert to their former belief.

In this light, one might start asking either "what is wrong with the Chinese or what is wrong with Islam?" Why is it difficult for the Chinese to welcome Islam while, in contrast, it is easy for them to embrace other religions without questions. Do they consider Islam an evil religion? Is it because of the people who claim to be Muslims but their acts are contradictory to the Islamic teachings? Or is it due to the widespread anti-Islamic propaganda in the mass media? To answer all these questions, an in-depth study is needed so as to avoid bias or generalization.

\section{HISTORY OF CHINESE ARRIVAL}

To better understand the Chinese in West Kalimantan, we first need to look back at the arrival of early Chinese settlers in Indonesia.

Although little is known for certain when the Chinese started coming to West Kalimantan, Herlianto (2001) in his work about the Chinese diaspora, argued that people from the Chin Dynasty (from which the word China itself is derived) had begun to visit the island of Java, Sumatra and Kalimantan in the 11 th century by ship. During the period of the Srivijaya Kingdom, the Chinese people began to settle in the coastal regions in Indonesia. But at that time their number was still small and their arrival done spontaneously.

In the 14th century, Chinese people began to establish colonies in Palembang. They mostly settled in the coastal areas. Many of them later assimilated with the local communities and left their ancestral traditions and culture. Between the 15th and 16th century, more and more came and established settlements on the islands of Java and Borneo, and their number is estimated at hundreds of thousands.

Eka Hendry (2007) in his work about the Chinese community in West Kalimantan stated that Chinese people arrived at this area around the 18th century. Most of them settled in Monterado and worked as gold miners. As mentioned earlier, that in accordance with historical accounts the Chinese may have visited West Kalimantan long before the 18th century because in the 11th century ships from China had already reached Sumatra, Java and Kalimantan. In addition, trade relations between the merchants in Guangdong and Fujian 
and those in West Kalimantan had been set up since the 16th century. In 1750s the wave of Chinese arrival in West Kalimantan was increasing in connection to the Borneo gold rush. Yuan (1998) in her book, Chinese Democracies, explains that it is generally thought that miners from China came to Borneo (as the island of Kalimantan is known to foreigners) around 1750 at the request of the Malay Sultanate due to their reputation as skilled miners and their mining technology. Economic and social difficulties may have triggered their migration to this province in the hope of a better future.

Over time, the Chinese miners and their descendants began to spread to different regions in the province. In contrast to the Chinese descendants on the island of Java, most of the Chinese descendants in West Kalimantan are able to maintain their culture and language. Even though they marry a native Indonesian, their children can still communicate orally in Hakka or Tiochiu - two of the most common Chinese dialects found in the province. High tolerance among the native peoples of West Kalimantan (Dayak and Malay) and the fact that the province is situated quite far from the capital city Jakarta may have somehow played a role in the maintenance of their language and culture.

\section{RELIGIOUS AND POLITICAL ISSUES}

Most of the Chinese in West Kalimantan embrace religions other than Islam. Many of them also still practice the ancestral beliefs. When Confucianism was approved as the official religion in Indonesia during Abdurrahman Wahid Administration, many of the Chinese reverted to it.

It is very uncommon to find a Chinese person practicing Islam. If one meets with a Chinese Muslim, he/she is usually a new convert. This conversion is mostly because of marriage. Religious contemplation may sometimes trigger the conversion but marriage is a more common reason. However, mixed marriage between the Chinese and Muslims are rare. Yuan (1998) writes that even though the Chinese were asked to come to West Kalimantan by the Malay, they did not mingle with them and marriage between them was not allowed.

Therefore, it could be assumed that not until recently has mixed marriage between the Chinese and Malays taken place as it has always been prohibited due to religious reasons or cultural incompatibilities. According to Veth, in Borneo's Wester-afdeeling, quoted by Yuan (1998), although the Malay language has become a lingua franca, there was no record of any Chinese having a Malay wife. It may have been not only due to the Chinese dislike of Islam but there must have been other incompatibilities as well, particularly the 
traditional practice of the Islamic teachings that was common in West Borneo at those times. In addition, the colonial Dutch policy did not promote interracial relations either as it aimed to keep the two groups separated.

This could shed some light as to why it is unusual for the Chinese to marry a Malay. The traditional Muslim men will be unlikely to marry a woman whose religion is other than Islam. If a woman is not a Muslim, she is expected to convert to Islam upon marriage. Similarly, the Chinese have long been known to always stick to their culture firmly. So it is also common for a Chinese man to find a woman of Chinese origin as a wife.

At this point, it is not surprising to find Chinese parents opposing their daughter's intermarriage. Incompatibilities between the Islamic teachings and the Chinese cultural practices could be assumed as the main reason. For instance, pork is forbidden in Islam while it is a delicacy in the Chinese cuisine.

When one looks back at the history of the early Chinese expeditions to areas that make up parts of the present-day Indonesia, one will come across an important figure, Cheng Ho. He was one of the earliest Chinese people who came to Indonesia. He was a Muslim Hui Chinese wholed maritime expeditions to Southeast Asia (including Java and Sumatera), South Asia, the Middle East, Somalia and the Swahili coast between 1405 to 1433 (Wikipedia.org). In Semarang, Central Java, a mosque was built in his honor.

\section{THE DILEMMA}

Converting to Islam for a Chinese person has often become a dilemma. Identity and ethnicity could be among the factors contributing to the gap between the Chinese society and the Malay Muslims in West Kalimantan. This new convert will experience an identity crisis or be in the state of losing their 'Chineseness'.

From the point of view of the Chinese, Islam seems synonymous with the Malay. Therefore, converting to Islam is regarded as becoming a Malay. The term for converting to Islam commonly used in Tiochiu dialect is jip huan (nyip fan in Hakka) which literally means 'enter into Malay' or 'becoming Malay'. This may cause reluctance among the Chinese to embrace Islam because the conversion is viewed as leaving their Chinese identity behind and sometimes may lead to family break-up.

However, conversion to Christianity does not seem to change anything as compared to Islam. The term in Tiochiu is jip ka (nyip kau in Hakka) which literally is 'enter into religious teachings'. It can therefore be assumed that converting to Islam means changing the identity to being Malay, whereas conversion to Christianity does not change anything. In other words, a Chinese 
converting to Islam is no longer Chinese but converting to Christianity remains Chinese.

Thus, one may wonder why conversion to Islam seems to be undesirable while Christianity is more acceptable to the Chinese. According to a Chinese Muslim respondent, one of the reasons might be that a Chinese Muslim will have problems participating in the activities of Chinese traditions or family events. For example, they will have trouble eating together at the family banquet which is usually held one day before the Chinese Lunar New Year as Islamic teachings are very strict with the concept of halal (permissible) and haram (forbidden) for certain foods and beverages. On the other hand a Chinese Christian can still join the family big meal. Amoy (a pseudonym), a Muslim converted Chinese, said that she no longer joined a family dinner since she converted to Islam. "Sometimes I feel sad that cannot participate in family gatherings. But what can I do? I guess this is the price I have to pay for my conversion" (interviewed in April 2008).

In addition, there are many other Chinese rituals and traditions that she can no longer perform after embracing Islam. For example when a member of her family died, she just came as a mourner and did not participate in the procession. This also may cause the Chinese to be reluctant to practice Islam as they have to skip family events, rituals and traditions. When a parent dies, there is usually a ritual of respecting the dead using incense stick which is considered syirik (polytheistic practice) in Islam.

Amoy further added that the way Muslim women should get dressed also contributes to the reluctance of conversion to Islam among Chinese women. In order to be a good Muslim, she wants to comply with the Islamic dress code by wearing a headscarf. According to Amoy, it was not easy for her at first to get used to the change in the dress code. She found it uncomfortable as her friends and relatives could easily notice that she is "no longer" Chinese. As discussed above that converting to Islam may cause a Chinese to lose their Chineseness because Islam is seen as the religion of the Malay, so becoming a Muslim is seen as becoming a Malay.

The headscarf is also often used as a 'weapon' to discredit Islam. The Muslim dress is often portrayed as inconvenient, inflexible, old-fashioned, etc. According to an anti-Islam propaganda page, wearing the hijab is a symbol of ignorance and harassment of women because women are treated like a genital organ that has to be covered. Oddly enough in the site does not mention anything about the Catholic nuns in Europe who also wear clothes that cover the entire body except the face and hands. 
Another possible root that causes the reluctance of the Chinese to embrace Islam is the less harmonious relations with their fellow indigenous Malays. The sour relations between the Malay and Chinese were due to several important factors in the history of Indonesia such as the ethnic classification policy that segregated the Chinese from other indigenous Indonesian peoples. The colonial Dutch strategy to keep the Chinese and the Malay (indigenous people) apart had proved to be effective in weakening the two groups and thus it was easier to maintain control over rebellious movements that might threaten the colonial government's rule. The Chinese were categorized as foreign orientals or second class citizens after the Europeans who were treated as first class. This ethnic segregation policy was part of the divide-and-rule politics exercised by the colonial Dutch government to quell the support of the Chinese for the indigenous peoples' fight against the colonial power.

Social jealousy toward the Chinese was deliberately and politically motivated so as to prevent the Chinese from becoming a threat to the colonial rule. Since this condition lasted for hundreds of years, the gap between the Chinese and the Malay (one of the major indigenous ethnic groups in West Kalimantan) has grown too wide to bridge. Mix marriage between the Chinese and Malays who are Muslims is less common compared to that between Chinese and Dayak and other ethnic groups that embrace Christianity.

\section{G/30S/PKI}

On September 30, 1965, several high ranking generals of the Indonesian Army were kidnapped and killed in Jakarta. It was part of a coup blamed on the defunct Indonesian Communist Party (PKI). The event is commonly known as the Rebellion of G30S/PKI. The abortive coup which led to the replacement of then President Soekarno by Soeharto, was allegedly supported by the People's Republic of China. In the wake of the event, hundreds of thousands of people labeled as members of the PKI were killed under the pretext of 'restoring order and stability'. Since the Chinese were regarded as the communist supporters, the New Order government under Soeharto adopted a policy that castrated the rights of the Chinese in the fields of politics and bureaucracy and directed them to concentrate in the economic related fields. This also gave rise to social jealousy because of the commonly held perception that the Chinese were in control of the economy. During economic crises, they often became the target of anger and disappointment in which their shops were looted, their houses burnt, and even there were reports of the mass rapes of ethnic Chinese women during riots in Jakarta in May 1998.

A number of riots that occurred during the New Order period and continued 
to take place during the early phases of reform era have further have to a certain degree affected the relations between the Chinese and indigenous Indonesians. Since the majority of Indonesians are Muslims, Islam is often seen as the religion of the indigenous Indonesians. Therefore the sour relations between the Chinese and indigenous Indonesians has also kept the Chinese from embracing Islam. According to an article published on the webpage of the University of Notre Dame Counseling Center, we are more likely to develop negative feelings about a particular racial group when we have little contact with the group. In addition, negative experiences with a member of the group will only strengthen the stereotype and create fears. It is these fears that further develop into an us-versus-them mentality.

Amoy herself reveals that it is not easy to change her family's view of Islam. Moreover, the negative stereotype about Islam is strengthening among the non-Muslim community. Islam is often portrayed as a religion repressive toward women. Amoy also reported in the interview (April 2008) that she was disappointed with Aa Gym for his decision to take another wife. She further added that she was terribly disturbed by news coverage in the mass media that tarnished the image of Islam especially related to the Islamic Defenders Front, Amrozi, Osama Bin Laden, the September 11 attacks in New York, the terror bombings in Madrid, London, Iraq and many other places. As reported in the mass media, the violent acts were carried out on behalf of Islam as if the religion is synonymous with being violent, intolerant, hateful and destructive. Global anti-Islam propaganda also appeared in Europe such as the emergence of the caricatures of the Prophet Muhammad in Denmark, the movie Fitna in the Netherlands all aimed at portraying Islam as a religion of hate.

As a convert, Amoy experienced a dilemma that is difficult for her to describe. On the one hand, she wants to show her family that Islam is a religion of peace, while on the other she is confused about various events reported by the media that tend to depict the negative stereotype about Islam.

\section{REFERENCE}

Hendri, Eka (2007). Mengenal Etnis Tionghoa di Kalbar. STAIN Pontianak. Herlianto (2001). Masalah Cina, $2^{\text {nd }}$ Article. http://www.yabina.org/artikel/ A5_01.HTM [accessed October 1, 2007]

Yuan, Bing Ling (1999). Chinese Democracies - A Study of the Kongsis of West Borneo (1776-1884).

www.en.wikipedia.org [accessed October 1, 2007]

www.wikipedia.com/west_kalimantan.html [accessed November 30, 2007] www.faithfreedom.com [accessed May 5, 2008] 
www.bbc.co.uk [accessed November 30, 2007]

http://ucc.nd.edu/self-help/multicultural-awareness/overcoming-stereotypes/ 